\title{
SOSIALISASI TANDA-TANDA BAHAYA BAYI BARU LAHIR DI PUSKESMAS GARUDA
}

\author{
Ani Triana
}

STIKes Hang Tuah Pekanbaru

\begin{abstract}
The vulnerable age of a baby is from the time the baby is born up to 28 days thereafter. At that time, if the baby has an abnormality or disorder, it will easily cause pain and death. At Garuda Public Health Center, there are still many mothers who do not know the danger signs of a newborn. The purpose of the activity is to increase knowledge and information about the danger signs of a newborn. The method of activity carried out is by conducting counseling on the danger signs of newborns. Implementation of activities on January 28, 2018. Before the counseling was conducted about questions to the audience, out of the 12 audience who attended, they did not know about the danger signs of newborns and did not know how to handle them. Then after counseling and examinations, it was found that the mother's knowledge had increased, from 12 audince 7 people understood about the danger signs of a newborn and its handling. The need for health workers to provide health education to mothers about the danger signs of a newborn, so that if the baby experiences one of the signs, the mother immediately takes action by coming to health services.
\end{abstract}

Keyword : Hazard Sign, Newborn

\begin{abstract}
ABSTRAK
Usia rentan seorang bayi adalah sejak bayi dilahirkan hingga 28 hari sesudahnya. Pada masa tersebut, jika bayi mengalami sesuatu kelainan ataupun gangguan maka akan mudah menimbulkan kesakitan hingga kematian. Di Puskesmas Garuda masih banyak ibuibu yang belum mengetahui tanda-tanda bahaya bayi baru lahir. Tujuan kegiatan untuk meningkatkan pengetahuan dan informasi tentang tanda-tanda bahaya bayi baru lahir. Metode kegiatan yang dilakukan adalah dengan melakukan penyuluhan tanda-tanda bahaya bayi baru lahir. Pelaksanaan kegiatan pada tanggal 28 Januari 2018. Sebelum dilakukan penyuluhan tentang dilakukan pertanyaan kepada audience, dari 12 audience yang hadir tidak mengetahui tentang tanda bahaya bayi baru lahir dan tidak tahu bagaimana penanganannya. Lalu setelah dilakukan penyuluhan dan pemeriksaan didapatkan pengetahuan ibu meningkat, dari 12 orang audince 7 orang mengerti tentang tanda-tanda bahaya bayi baru lahir dan penanganannya. Perlunya tenaga kesehatan harus memberikan pendidikan kesehatan pada ibu tentang tanda bahaya bayi baru lahir, sehingga jika bayinya mengalami salah satu tanda ibu langsung segera bertindak dengan datang ke pelayanan kesehatan.

Kata Kunci

: Tanda Bahaya, Bayi Baru Lahir

\section{PENDAHULUAN}

Usia rentan seorang bayi adalah sejak bayi dilahirkan hingga 28 hari

sesudahnya. Pada masa tersebut, jika bayi mengalami sesuatu kelainan ataupun gangguan maka akan mudah
\end{abstract}


menimbulkan kesakitan hingga kematian. Angka kematian BBL di indonesia sangat tinggi, bahkan yang tertinggi di kawasan Asia tenggara. sebanyak 401 bayi lahir di indonesia meninggal berumur satu tahun setiap harinya. Dari angka tersebut berarti tiap menit ada 1 bayi indonesia meninggal (Sudarti, 2010).

Sepertiga kasus dari angka kematian bayi terjadi dalam satu bulan sesudah kelahiran. Sebanyak $80 \%$ di antaranya terjadi pada minggu pertama. Fakta menyedihkan itu menurut Dr. Budihardja, DTM dan H,MPH, direktur jendral bina kesehatan masyarakat Depkes RI dipengaruhi oleh banyak faktor. Utamanya, hal ini timbul karena daya tahan tubuh bayi baru lahir yang masih lemah, dan pengetahuan para ibu yang masih kurang mengenai bagaimana menjaga kesehatan bayinya (Sudarti, 2010).

Angka kematian anak tetap menjadi masalah serius di Indonesia beberapa penyebab kematian bayi baru lahir(neonates) yang terbanyak disebabkan oleh kegawatdaruratan dan penyulit pada masa neonates seperti berat bayi lahir rendah, asfiksia neonatorum, syndrome gawat nafas, hiperbilirubinemia, sepsis neonatorum, trauma lahir dan kelainan congenital. Penyebab langsung kematian neonates adalah infeksi(32\%), asfiksia(29\%) (Depkes RI, 2012).

Kematian bayi baru lahir (87\%) dapat dicegah apabila deteksi dini bayi resiko cepat diketahui, dan dapat segera dirujuk agar mendapat pertolongan yang akurat, dan cepat. Diperkirakan tiap jam terdapat 12 neonatus meninggal. Bayi yang berumur kurang dari tujuh hari, kelainan yang diderita lebih banyak terkait dengan kehamilan dan persalinan, sedangkan bayi berumur lebih dari tujuh hari sampai dua bulan banyak terkait dengan pola penyakit anak. Karena kebanyakan bayi baru lahir yang sakit jarang dibawa oleh orang tua ke pusat pelayanan karena kultur masyarakat (Indarso, 2012).

\section{Perumusan Masalah}

Di Puskesmas Garuda masih banyak ibu-ibu yang belum mengetahui tanda-tanda bahaya bayi baru lahir. Oleh karena itu penulis tertarik melakukan pengabdian masyarakat tentang "Sosialisasi Tanda-tanda Bahaya Bayi Baru Lahir di Puskesmas Garuda" 


\section{TUJUAN KEGIATAN}

Untuk meningkatkan pengetahuan dan informasi tentang tanda-tanda bahaya bayi baru lahir.

\section{METODE}

Metode kegiatan yang dilakukan adalah dengan melakukan penyuluhan tanda-tanda bahaya bayi baru lahir.

\section{HASIL}

Sebelum dilakukan penyuluhan tentang dilakukan pertanyaan kepada audience, dari 12 audience yang hadir tidak mengetahui tentang tanda bahaya bayi baru lahir dan tidak tahu bagaimana penanganannya. Lalu setelah dilakukan penyuluhan dan pemeriksaan didapatkan pengetahuan ibu meningkat, dari 12 orang audince 7 orang mengerti tentang tanda-tanda bahaya bayi baru lahir dan penanganannya.

\section{PEMBAHASAN}

Pelaksanaan kegiatan dilakukan di Puskesmas Garuda. Dihadiri sebanyak 12 orang audience.

Susunan acara sebagai berikut: Pembukaan 5 menit oleh moderator Ani Triana, SST, M.Kes. Kegiatan Penyuluhan pada pendahuluan pertama yaitu menyampaikan salam, kedua menjelaskan tujuan kemudian kontrak waktu. Kegiatan audience Membalas, Mendengarkan dan Memberi respon. kemudian acara inti 15 menit materi penyuluhan disampaikan oleh Yunita Rahayu sebagai pemateri, isi materi Pengertian tanda-tanda bahaya bayi baru lahir, Ciri-ciri tanda bahaya bayi baru lahir, Penatalaksanaan dan Kondisi yang perlu penanganan awal. Kegiatan audience Menanyakan yang belum jelas. Aktif bersama menyimpulkan, membalas salam dan terakhir penutup 10 menit . Kegiatan selanjutnya yaitu tanya jawab, tes akhir, menyimpulkan hasil penyuluhan dan memberi salam. Penutup. 
Kegiatan audience bu menanyakan yang belum jelas, aktif bersama menyimpulkan dan memberikan dorprize pada audience yang dapat menjawab pertanyaan yang diberikan moderator.

\section{KESIMPULAN}

Berdasarkan kegiatan pengabdian kepada masyarakat tersebut yang dihadiri 12 orang audience, dari 12 orang audince 7 orang mengerti tentang tanda-tanda bahaya bayi baru lahir dan penanganannya.

\section{SARAN}

Diharapkan kepada tenaga kesehatan harus memberikan pendidikan kesehatan pada ibu tentang tanda bahaya bayi baru lahir, sehingga jika bayinya mengalami salah satu tanda ibu langsung segera bertindak dengan datang ke pelayanan kesehatan.

\section{DAFTAR PUSTAKA}

Abbas, et al. (2014). Panduan imunisasi.Yogyakarta: salemba medika

Hidayat, A.A. (2012).Pengantar ilmu Kesehatan anak untuk pendidikan kebidanan.Jakarta : Salemba Medika

Marmi dan Kukuh, R. (2012).Asuhan Neonatus, Bayi, Balita, dan Anak Prasekolah, Yogyakarta: Pustaka Pelajar.

Prasetyawati, A.E. (2012). Kesehatan Ibu Dan Anak (KIA) Dalam Millenium Development Goals $(M D G s)$.Yogyakarta : Nuha Medika. Probandari, A.N., Handayani, dan Laksono, N.J.D.N. (2013). Asuhan Neonatus, Bayi, Balita, dan Anak Prasekolah, Yogyakarta: Pustaka Pelajar 